\title{
The Transference of Discourse Values in Translation via Lexis: Obscene Language as a Case in Point
}

\section{Ma Jesús Pérez Quintero and Carmen Toledano Buendía University of La Laguna mjperezq@ull.es; ctoledan@ull.es}

\begin{abstract}
The aim of this paper is to show the important role played by lexical choices in translation, considered not only as a means of rendering a direct equivalent in the target language, but also a means of manipulation motivated by the target reader's demands. We will present the new conception of the lexicon provided by the Functional-Lexematic Model in order to analyze, later, the advantages of this model for the study of lexical choices in translation. In analyzing different translations from this point of view, we will concentrate on the lexical field of obscenity.
\end{abstract}

\section{Introduction}

Taking a functional view of language, we could say that a language is just a means of communication, used by a speaker with the intention of transmitting a message to an addressee. For that purpose, the speaker selects a number of appropriate lexical items from his/her mental lexicon and combines them into higher units (phrases, sentences, texts or discourse). In the same way, it could be stated that translation is also a means of communication, the difference lying in the fact that what the translator does is to transmit a message, originally rendered in a different language, to an addressee. Therefore, $s /$ he must search for correspondences or equivalencies at different levels (textual, grammatical, lexical) in order to convey the same meaning in the target language. 
Within the functional paradigm, in recent times, there is a main concern with discourse analysis or text linguistics, since it is emphasized that communication is not carried out through isolated words or sentences but through higher units, i.e. texts or discourse. From our perspective, it is precisely this view that has been influential in translation studies, considering, therefore, that the translator's main task is the rendering of a textual/discourse equivalent in the target language, thus belittling the importance of lexical choices.

In our opinion, this current situation is deeply rooted in two misconceptions. Firstly, there is the widespread idea that discourse analysis has nothing to do with grammar or grammatical units. In this respect, Halliday argues:

A text is a semantic unit, not a grammatical one. But meanings are realized through wordings; and without a theory of wordings -that is, a grammar-there is no way of making explicit one's interpretation of the meaning of a text (1985: xvii).

Therefore, it should be clear that textual meaning is the result of the combination of different elements that make up the text and, therefore, choices at lower level, i.e. lexical choices, play an important role in the overall organization of the text.

Secondly, the rejection of the importance of lexical choices in translation is based on the conception of the lexicon of a language as a list of words alphabetically ordered and provided with a definition, as is the case of most monolingual dictionaries, or a direct equivalent in the other language, as found in the bilingual ones. If this were the case, it would be very easy to translate from one language to the other, since the only task of the translator would be to replace words in the source language by their equivalents in the target language. Nevertheless, translation experience proves that this is not the case. Snell-Hornby mentions the following with respect to this issue:

The reason for this lies firstly in the frequent discrepancy between lexemes viewed in isolation and their usage as words in contexts, and secondly in a misguided but deep-seated view of interlingual equivalence, in the conviction that a word in one language must not necessarily be lexicalized to fulfil the same function in another language. Such a simplistic belief is refuted continually by the experience of anyone who works intensively with at least two languages in their concrete realization (1990: 209-210).

In this paper we present a new conception of the organization of the lexicon of a language provided by the Functional-Lexematic Model (henceforth FLM) elaborated by Martín Mingorance $(1984,1987,1990,1995)$, in order to explore, later, its advantages for the analysis of the role played by lexical units in translation. Specifically, special attention will be paid to aspects of lexical manipulation in the translation of obscenity. 


\section{The Functional-Lexematic Model}

The FLM constitutes an integrated model that enriches Coseriu's Lexematics with Dik's Functional Grammar (henceforth FG), together with some contributions of cognitive linguistics.

Coseriu's Lexematics as well as Dik's FG have in common the functional approach adopted for the description of lexical units. The first one is structurally functional in the sense that lexical units are analyzed according to the principle of functional oppositions. The latter is teleologically functional in the sense that its basic methodological principle states that the function of a language is to serve as an instrument of verbal interaction.

On the other hand, these two models are complementary, since they constitute different types of grammatical analyses. Coseriu's Lexematics adopts an analytic model, characterized by organizing the vocabulary of a language in lexical domains, thus, developing the so-called paradigmatic axis. Dik's FG belongs to the synthetic type, i.e. it has been devised from the encoder's point of view, concentrating on the syntagmatic features of units.

The starting point for this new conception of the lexicon provided by the FLM is the idea that the lexicon is the primary means to categorize and, therefore, conceptualize the world. Each language organizes the world differently and, consequently, the lexicon of a language reflects "the divisions and sub-divisions 'imposed' by a given linguistic community on the continuum of experience" (Baker, 1992: 18).

Thus, within the FLM, the description of the lexicon must take into account a variety of factors that make up the lexical competence of a speaker. In this model, a word is conceived as a micro-grammar or micro-text that codifies and, consequently, activates information of different types. Mairal Usón describes this conception of a word as follows:

una entrada léxica pasa a concebirse como un discurso donde confluyen factores lingüísticos y textuales $[\ldots]$, así como culturales y antropolingüísticos [...]. En el lexicón plenamente especificado del MLF [FLM], la palabra es la unidad básica de descripción, y por ello se representa con todas sus propiedades sintácticas, morfológicas, semánticas y pragmáticas. El lexicón se concibe, por tanto, como una red dinámica orientada hacia el texto, con información sobre las palabras y sus correlatos contextuales (1999: 70).

The different types of properties or information associated with each word in the lexicon, is coded in the FLM around four axes: (a) paradigmatic, (b) syntagmatic, (c) cognitive and (d) pragmatic.

\section{(a) Paradigmatic axis}

Paradigmatic structure concerns basic lexical organization. The problem of most dictionaries is that the different lexical entries are rendered in alphabetical order, organization that doesn't correspond to the way we store words in our mind. However, if the aim is to account for the mental organization of words, a relational approach to the 
lexicon must be adopted. In this sense, the FLM adopts an onomasiological organization, in which primary lexical entries are grouped into domains and subdomains. ${ }^{1}$ The group of subdomains that are part of the same domain make up its semantic architecture. The elaboration of these (sub)domains constitutes the paradigmatic axis of the lexicon, based on the relations of opposition existing between words and motivated by their substitution possibilities.

Each lexical domain contains a more general word or superordinate term, in terms of which all the other members of the domain are defined. Through the application of the procedure of Stepwise Lexical Decomposition (Dik, 1978), the semantic organization of each of the different lexical (sub)domains is arrived at. Each domain is constituted by a group of lexemes that share a common area of signification and that, at the same time, are distinguished from one another by at least one minimal feature or seme, since they focalize specific areas of meaning.

The internal configuration of each (sub)domain is provided by a more prototypical term or archilexeme plus a number of more specific lexemes or hyponyms, defined in terms of their hyperonyms. The result of this process is a hierarchical configuration of the definitions. As a way of example, consider the semantic architecture provided by Faber and Mairal Usón (1999: 255) for the subdomain 'to become worse':

worsen to become worse (more difficult/unpleasant/unacceptable/severe).

deteriorate to worsen in condition or quality [formal].

spoil to deteriorate (esp. of food).

decay to deteriorate physically in a visible way because of chemical changes.

molder to decay slowly (of something left in a place).

rot to decay slowly with an unpleasant appearance or smell.

putrefy to rot, giving off a very strong, unpleasant smell.

decompose to decay by breaking up into simple parts (of something organic).

This subdomain is part of the lexical domain of CHANGE, in terms of which the other members of this domain are defined (i.e. worsen can be defined as 'to change by becoming worse', as opposed to improve 'to change by becoming better'). In this subdomain, the most general term or archilexeme is worsen, in terms of which different hyponyms or more specific lexemes are defined (i.e. deteriorate is 'to worsen in condition or quality [formal]').

As the display of the subdomain illustrates, there is a hierarchical organization in which more specific terms are defined in terms of more general ones. The advantage of this organization is twofold, since it is relevant in order to account for both intra- and interlinguistic relations. As regards the latter, this hierarchy allows us to establish isosemic and anisosemic ${ }^{2}$ lexical relations. Through a contrastive analysis of the same lexical domain in different languages, it would be possible to detect the (non-)existence of lexical correspondences. In this respect, Snell-Hornby comments:

The dictionary should rather aim at pinpointing the focal components of the lexeme concerned and at situating it both paradigmatically (or intralinguistically) and contrastively (or 
interlinguistically), i.e. both against other items in the semantic fields concerned and in contrast to similar items in the target language.

This would mean, however, abandoning the age-old lexicographic tradition of isolated lexemes in alphabetical order and the expectation of the immediately insertable equivalent (1990: 222).

\section{(b) Syntagmatic axis}

The paradigmatic axis must be complemented with the syntagmatic one. Whereas the first describes the substitution possibilities of a lexeme, the syntagmatic axis concentrates on its combinatorial properties. Thus, it provides the information relevant for the correct use of a lexeme in discourse. The basic underlying idea is the belief that the lexicon of a language should contain all the syntactic features or complementation patterns of predicates. ${ }^{3}$ The syntagmatic description is rendered using Dik's (1997) concept of predicate frame. According to Dik, in the lexicon, the predicates of a language are not described in isolation, but together with a structure or frame that provides all the basic information needed in order for the predicate to be inserted in a linguistic expression. Thus, the predicate frame includes the following information: (i) the form of the predicate, (ii) the syntactic category (noun, verb and adjective), ${ }^{4}$ (iii) the quantitative valency or number of arguments required by the predicate and (iv) the qualitative valency, specified by means of the semantic roles assigned to the arguments and the selection restrictions imposed on the type of elements that can be inserted in the argument slots.

The following example illustrates the relevance of the information codified in the syntagmatic axis for the meaning of a word:

$$
\begin{aligned}
& \text { give head }_{\mathrm{V}}:\left(\mathrm{x}_{1}: \operatorname{woman}_{\mathrm{N}}\right)_{\mathrm{Ag}}\left(\mathrm{x}_{2}: \operatorname{man}_{\mathrm{N}}\right)_{\mathrm{Go}} \\
& \text { e.g. She gave him head }=\text { She sucked it to him } \\
& \text { give head }:\left(\mathrm{x}_{1}: \operatorname{man}_{\mathrm{N}}\right)_{\mathrm{Ag}}\left(\mathrm{x}_{2}: \text { woman }_{\mathrm{N}}\right)_{\mathrm{Go}} \\
& \text { e.g. He gave her some head }=\text { He fucked her }
\end{aligned}
$$

Although the paradigmatic and syntagmatic axes have been described separately, it is important to keep in mind that they are highly interrelated, since their intersection is what provides the meaning of a word. In this sense, Calañas Continente states:

it is important to bear in mind that it is impossible to dissociate the paradigmatic and the syntagmatic axis, since both are interdependent [...] and the information given by both of them add up to the meaning of a lexical item (1998: 29).

The intersection of these two axes is said to give place to a series of so-called predicate schemata. The complementation patterns of a predicate, provided by the syntagmatic axis, are motivated by the semantic subdomain (paradigmatic axis) to which it belongs or, as Faber and Mairal Usón put it: "the meaning of a word systematically interacts with its grammatical properties" (1998: 7). 
Given that interrelation, Mairal Usón formulates the following Principle of Lexical Iconicity: "The greater the semantic coverage of a lexeme is, the greater its syntactic variation. The more prototypical a term is, the more prototypical effects it will show" (1999: 85).

\section{(c) Cognitive axis}

The cognitive axis, "the intersection point of language and thought" (Faber and Mairal Usón, 1999: 203), implies the elaboration of a classification of the prototypical conceptual schemata within each lexical domain, that is, the classification of the semantic and syntactic prototypes in each domain. The information provided by this axis allows us to account for cognitive abilities, defined by Fernández Sánchez as "the capacity of human beings to categorize and make sense of experience in terms of more basic or concrete domains" (1998: 65). Among these cognitive abilities metaphors and metonyms are the most prominent ones. ${ }^{5}$

Faber and Mairal Usón point out the importance of the cognitive axis for translation, since, if lexical units are the external representation of our conception of the world, "to translate a text from one language to another, there must be a conceptual representation shared by both" (1999: 203).

As an example, we can consider the metaphor of women as containers and men as forces that penetrate, that accounts for the meaning of 'penetrate' (i.e. (of a man) to insert the penis into the vagina (of a woman)) or the allusions to the male organ as a weapon. ${ }^{6}$

Since the cognitive axis accounts for cross-domain behavior of lexical units, it could still be considered a separate axis, though highly interrelated with the paradigmatic and the syntagmatic one.

\section{(d) Pragmatic axis}

With regards to the pragmatic axis, Martin Mingorance states that it "is mainly concerned with the communicative strategies, not so much with rules" (1998: 96). It deals, therefore, with what is generally considered the connotative or emotive meaning of lexical units. This type of meaning has been traditionally (Lyons, 1977; Leech, 1974) considered secondary and, consequently, has received little attention in lexical studies. The main reason for this has been the conception that connotative or emotive/affective meanings belong to the outside world and not to language. In this respect, Leech's explanation of connotation is quite revealing:

It will be clear that in talking about connotation, I am in fact talking about the 'real world' experience one associates with an expression when one uses or hears it. Therefore the boundary between conceptual and connotative meaning is coincident with that nebulous but crucial boundary,..., between 'language' and the 'real world' (1974: 15). 
Likewise, what this author calls affective meaning is associated with the extralinguistic reality, since it is related to the speaker's personal opinions and to his/her attitude towards the addressee or the message.

Within the FLM, this type of information is not secondary but receives due importance within the definition of lexical units. That this is so is not surprising if we take into account that this model shares the basic methodological principle of FG, according to which languages are considered instruments of verbal interaction and, consequently, semantics cannot be conceived independently from pragmatics. The FLM tries to integrate this functional conception of language in the definition of words through the recognition of the pragmatic axis.

The deepest analysis of this axis has been undertaken by Jiménez Hurtado $(1997 ; 1998)$, who emphasizes the importance of introducing pragmatic information in the lexicon:

La pragmática léxica, tal como la consideramos en este artículo, ha sufrido, sobre todo en los últimos años, innumerables y valiosas aportaciones que se han centrado en la necesidad de incluir información acerca del contexto de situación en el que se emplea la unidad léxica analizada, es decir, información acerca del emisor, el receptor y la situación comunicativa prototípica en la que la misma es susceptible de ser actualizada [...] Por otro lado se ha venido reivindicando la necesidad de establecer y analizar, también desde el punto de vista léxico, la relación entre unidad léxica y sentido textual o lo que es lo mismo, el análisis de la responsabilidad semántica de cada unidad léxica en el texto en el que ha sido actualizada (1998: 276).

This author distinguishes different types of pragmatic information coded in the lexicon, which she labels pragmatic prototypes. The first type of pragmatic information is associated with what she calls "variedades dia-", which include diatopic (related to geographic distinctions), diastratic (associated with socio-cultural values and status) and diaphasic (related to different registers and styles).

The second type of pragmatic information results from the conception of a lexical field as a discourse. This conception implies the application of the notions of topicality and focality, traditionally associated with the organization of information in the sentence, to the analysis of lexical units. The result of this analysis affects the configuration of each field in the following way:

Cercanos al prototipo de cada campo se encuentran los lexemas que se integran en dimensiones que prácticamente coinciden con él en tópicos; conforme se avanza en el recorrido por el campo léxico, se añade información nueva que se refleja en la creación de nuevas dimensiones que cada vez se van apartando más del prototipo con la inserción de nuevos tópicos y focos (Jiménez Hurtado, 1998: 283-284).

The third type of pragmatic information is constituted by a group of cognitive paiterns of a socio-cultural nature. Jiménez Hurtado distinguishes two types of patterns. A primary one referring to the evaluation on the part of the speaker according to an axiological scale (taken 
from Krzeszowski, 1990) and a secondary one associated with biological and /or sociocultural norms established by a society and essential in determining the axiological load of a lexeme. The lexicon of a language is not only the means human beings have in order to categorize the world, but also the means we have in order to evaluate it. As Faber and Mairal Usón remark: "the fact is that we are constantly evaluating our world in terms of sensory impressions of what is pleasurable for us and what is not" (1997: 30). Krzeszowski (1990) establishes an axiological scale, the good-bad scale, and he claims that all lexical items can be analyzed in terms of this scale. Even more, he posits an axiological principle formulated as follows: "Words have a tendency to be axiologically loaded with 'good' or 'bad' connotations in proportion to the degree of the human factor associated with them" (1990: 150).

Moreover, the axiological load of a word depends on the socio-cultural context, the historical period or even experience. To this respect, Jiménez Hurtado explains that:

Cuando la comunidad cultural establece una serie de valoraciones lo hace pues en función de esas normas que afectan a los individuos como seres físicos (normas sensitivas) y a su interacción con el entrono más inmediato (normas socioculturales) (1998: 287).

This author offers a list of norms distributed in four groups: -sensitive macro-norms, which include biological, hedonistic and emotive norms; -socio-cultural macro-norms, which comprise ethical norms (including ethical and religious micro-norms) and social norms (including scientific, legal, politic and economic micro-norms); -aesthetic macro-norms and-noetic macro-norms.

The last type of pragmatic information includes those aspects that condition the inclusion of a lexical unit in the discourse. In this sense, it is interesting to analyze, not only the contribution of the chosen lexical unit (in opposition to other close units) to the overall meaning of the text, but also the relation between the different lexemes present in the text.

The pragmatic axis, although described separately within the FLM, could be included in the paradigmatic one, since the information it provides, as will be seen below, is part of the definition of the different lexemes and becomes relevant for the distinction of the different (sub)domains. If every lexical entry is defined as a micro-discourse, one cannot refer to pragmatic information as a separate axis, instead one can argue that paradigmatic information should be pragmatically oriented. In other words, information relative to sociocultural norms and, thus, to axiological load, can be coded as (pragmatic) semes at the same level as the exclusively denotative semes. As Krzeskowski claims: "all lexical items are assessable on an axiological scale and that the amount of the axiological load is semantically relevant" (1990: 138).

In order to illustrate the incorporation of pragmatic information into the paradigmatic axis, we present the lexical subdomain of 'to have sex with / practicar el sexo' in English and Spanish. 
Have sex with: to perform the act of sex.
Make love: to have sex with someone you love.
Have (sexual) intercourse: to have sex; formal.
Copulate: [applied to people] to have sex; formal or
literary.
Lose one's virginity: to have sex for the first time in
one's life.

Sleep with (/together): to have sex with, and usually spend the night with, someone people think you should not have sex with.

Go to bed with: to have sex with, usually on one occasion; euphemism.

Bed someone: to go to bed with; informal.

Fornicate: to have sex with someone who you are not married to; formal or biblical, used showing disapproval.

Have: to have sex with; informal.

Make it: to have sex with; slang.

Score: to have sex with; slang.

Fuck: (esp. of a man) to have sex with; taboo.

Screw: (esp. of a man) to have sex with; taboo, slang.

Lay: (esp, of a man) to have sex with; slang, offensive.

Give a woman some head: (esp. of a man) to have sex with; slang, offensive.

Knock off: (esp. of a man) to have sex with; slang, esp. BrE.

Make (with): (esp. of a man) to succeed in having sex with; slang, informal, esp. AmE.

Sleep around: to have sex with a lot of people; informal, used showing disapproval.

Mate: to have sex, applied to animals in order to produce babies.
Practicar el sexo: realizar el acto sexual.

Hacer el amor: practicar el sexo con alguien al que se ama.

Tener relaciones (sexuales): practicar el sexo; formal.

Copular: [aplicado a personas] practicar el sexo; formal.

Perder la virginidad: practicar el sexo por primera vez en la vida.

Acostarse con: practicar el sexo con alguien con el la gente piensa que no se debería.

Irse a la cama con: practicar el sexo con alguien, normalmente una sola vez.

Fornicar: practicar el sexo con una persona con la que no se está casado; formal / bíblico.

Hacerlo: practicar el sexo; coloquial.

Joder: practicar el sexo; vulgar.

Follar: practicar el sexo; vulgar.

Follarse: practicar el sexo; vulgar, despreciativo.

Cepillarse: (esp. de un hombre) practicar el sexo; vulgar, despreciativo.

Tirarse: (esp. de un hornbre) practicar el sexo; vulgar, despreciativo.

Aparearse: practicar el sexo, entre animales para la reproducción.

It is interesting to notice that, both in English and in Spanish, the concepts that are lexicalized are characterized by a negative axiological load. The more neutral concepts are not lexicalized but expressed by means of periphrastic constructions. Moreover, the fact that most of these verbs are said to be applied especially to men, is related to the metaphor we commented before of the woman as a container and the man as the force that penetrates and, therefore, the agent of these actions. 


\section{Analysis of translations}

In this section we will apply the FLM conception of the lexicon presented above to the analysis of some translations, concentrating on the role played by lexical choices.

The choice of a literary text to be translated is not at all a fortuitous one. Translations obey specific cultural norms and demands and, therefore, they must be placed and analyzed in a specific context. Thus, the decision of translating a literary work requires a previous evaluation of the possibilities of acceptance and assimilation of that work in the light of the socio-cultural norms of a certain community. This general assumption is even more evident in the case of the translation of obscenity, that could be considered one of the most axiologically marked concepts from a socio-cultural perspective.

The fact that, in deciding to translate an obscene literary text, there is always a previous evaluation of the suitability of this translation has led to two different situations: not translating the text and translating it with some "adaptations". An example of the first situation, not analyzed here for obvious reasons, would be the novel Memoirs of a Woman of Pleasure, written by John Cleland in 1749 . This novel was perceived as highly obscene and transgressive in the $18^{\text {th }}$ century in Spain and, therefore, it was forbidden and considered inappropriate for translation. ${ }^{\text {? }}$

The second situation is the one that would be taken into consideration here. We will then analyze the appropriateness of the lexical choices undertaken in the process of translating some literary texts which included elements, at different levels, considered to be obscene. ${ }^{8}$ The translations used are: Pamela Andrews ó La virtud premiada by Samuel Richardson (1799), Tom Jones ó El Expósito by Henry Fielding (1796), Viages del Capitan Lemuel Gulliver á diversos paises remotos by Jonathan Swift (1800), Aventuras de Robinson Crusoe by Daniel Defoe $(1846 ; 1849-50)$ and Fanny Hill $(1977 ; 1978)$. The importance of these texts lays in the fact that they constitute the first complete Spanish translations published in our country. ${ }^{9}$

The study of the field of obscenity leads to a main concern in the pragmatic information, which we have considered to be part of the paradigmatic axis. Therefore, it is not surprising that most of the examples are related to this axis, examples associated with the syntagmatic and the cognitive axes being less numerous.

As regards the syntagmatic axis, we will present two illustrative examples. The first one, taken form Pamela, is a fragment in which Lady Davers refers to the relationship held between Pamela and her brother:

'...confess the truth', answered she, 'that thou art an undone creature; hast been in bed with thy master; and art sorry for it, and for the mischied thou hast caused between him and me...(1985 [1740]: 422).

Confiesa la verdad, me dixo, confiesa que eres una muger abandonada, que te has dexado seducir por tu amo, y que estás ya arrepentida de esto, y de las discordias que entre los dos has sembrado ... (1799, Vol. IV: 45). 
In the source text we have the predicate "undone", that has a controller argument "creature", as well as "hast been in bed with thy master" with the predicate "to be in bed with" that also requires a willing controller of the State of Affairs. However, in the target text, the translator has chosen two predicates "abandonada ('abandoned')" ${ }^{10}$ and "dejarse seducir ('easily seduced')", which require a Processed argument. This change in the syntagmatics causes a significant change in the characterization of Pamela, who in the source text is presented as a controller and, thus, as a volitional entity, whereas in the target text is simply a Processed, an affected entity.

The second example, taken from Fanny Hill, concerns the translation of "giddy creatures", that is rendered as "alocadas criaturas" in the 1977 version and as "criaturas casquivanas" in the 1978 version. The combination adjective + noun in Spanish is marked and, therefore, is more emphatic than the unmarked order (i.e. "criaturas alocadas"). In the second translation, however, the unmarked order in Spanish is provided but the emphasis lies in the fact that the word chosen, "casquivanas ('frivolous flighty')", has more explicit sexual connotations than "alocadas".

As regards the cognitive axis, we will comment on three different metaphors that are actively used in Fanny Hill. In the source text, the author creates a botanic metaphor in order to refer to the female organ, "the young tendrils of that moss" (1985 (1749]: 49), metaphor that is kept in the 1977 translation, "tiernos brotecillos de musgo" (1977: 16), but that is partially lost in the 1978 version, where the word "tendrils" is rendered as "rizos ('curls')" ("los rizos de aquel musgo" (1978: 29)), making a more explicit reference and thus lessening the botanic connotations. The same situation is later repeated, since "the dark umbrage of the downy spring-moss that over-arched it" (1985 [1749]: 153) is translated as "la oscura sombra de sutil musgo primaveral que lo cobijaba" (1977: 135) and "la sombra oscura del vellón ('down') que lo cubría" (1978: 137). In the second translation again, the connection of "umbrage" (shade or shadow as cast by trees) with "spring-moss" is lost, since no mention to botanics is made.

The second example, also used to refer to the female organ, illustrates the container metaphor. Cleland uses the expression "cloven inlet" (1985 [1749]: 171), in which "inlet" is clearly associated with the conception of the sexual organ of a woman as a container that "lets in" the male penetrator. In the 1977 version, "la puerta de dos hojas" (1977: 156), the metaphor is kept, although with a more euphemistic tone. However, the second version completely avoidis this metaphoric interpretation, providing just an euphemism, "la parte hendida ('sunken')" (1978: 155).

Whereas the two previous examples of metaphors were present in the source text and maintained in the 1977 translation but not in the 1978 one, in the third example the situation is just the opposite. The source expression is "coarse couniry strammel", that is almost literally translated in 1977 as "aquella tosca moza campesina", while in 1978 it is rendered by means of the mounts metaphor, "ruda jaca ('mare') labriega".

As was mentioned before, the problem of lexical choices in translating obscenity arc mainly connected with the paradigmatic axis, which provides the meaning of a word. It must be kept in mind that the meaning of a word, as it is understood here, is the combination of 
its objective meaning and its pragmatic implications (stylistic and evaluative associations) and, therefore, the translator's lexical choices condition and must be conditioned by the maintenance of a series of expressive choices present in the original text.

The common feature to the lexemes that are being analyzed is their negative axiological load. There is no doubt that most of the words belonging to the field of obscenity are characterized by a negative evaluation, imposed by socio-cultural norms. The translator, influenced by the target society's demand, uses three different strategies:

- complete omission of the negative evaluation

- mitigation of the negative evaluation

augmentation of the negative evaluation

The first of these strategies is quite frequent in the analyzed texts, so it could be considered a general practice in the prose translation policy of the time. Nevertheless, the corpus used for the analysis is not large enough to draw such a conclusion, which, on the other hand, is beyond the aim of this paper. The few insults ("be damn'd; G-d damme's") used as interjections by the English inhabitants of Robinson Crusoe's island are omitted in the translation. The same can be observed in relation to the insults that Lady Davers and her nephew address to Pamela ("whore; wench; young harlot..."). Likewise, the rude vocabulary ("son of a $b$---; resent my ass; son of a whore") that characterizes Mr. Western's speech in Tom Jones is not mentioned at all in the target text. The translator of Pamela avoids mentioning all affective words used by Mr. B to address his lover ("dear, good girl; my charming girl; my dear Pamela; my dearest girl; my beloved girl; my Pamela; my love; my charmer!; my angel; my lovely bride; my sweet Pamela..."). ${ }^{11}$

Explicit mention to physical (-sexual) contact is also avoided, especially in Pamela, both before and after marriage. These are some of the fragments that are omitted:

- 'Hide your dear face in my bosom, my beloved Pamela' (1985 [1740]: 256).

- 'And so, Pamela, give me your hand, and one kiss, and then I am gone'. I durst not refuse (1985 [1740]: 259).

- This very day shall make you mine (1985 [1740]: 357)

- 'sweet good girl', he called me, and folded me to his bosom (1985 [1740]: 366)

- with his arms about me as we walked (1985 [1740]: 512)

The strategy of omission is even more important when Pamela is the narrator, since, as she declares in the Spanish version, "Me dixo otras muchas cosas que omito deciros, porque no parecieran bien en mi boca" (1799, Vol. I: 25). This can be seen in the following example:

People indeed say I am handsome; but if I am, should not a gentleman prefer an honest servant to a guilty harlot? (1985 [1740]: 158$)^{12}$

Dicen que tengo alguna belleza; pero aunque fuera asi; ¿ no deberia un caballero preferir una criada honrada á una que no lo fuese? (1799, Vol. II: 6) 
In the translation of Gulliver's travels, some details of the physical description of the yahoos are omitted:

They had no tails, nor hair at all on their buttocks, except about the anus (1985 [1726]:

269-270)

Tampoco tenían cola (1800, Vol. III: 105)

It is important to keep in mind that the omission of obscene words in the translations is not due to a lack of direct equivalents in the target language but to the deliberate decision of the translator to omit what he considers "inappropriate" for the target community.

The second strategy commonly used by translators when coping with obscene elements in these $18^{\text {th }}$ century texts is that of mitigation. Mitigation is achieved by three different means.

On some occasions, the obscene word is translated by a word that belongs to the same domain but that lacks the seme of 'negative evaluation'. In Defoe's Robinson Crusoe, for instance, the hyponym " $G$-d damme's" in "mixing two or three G-d damme's" (1990 [1719]: 281 ) is translated by the superordinate "tacos ('swearword')", as in "mezclando dos o tres tacos" (1849, Vol. II: 47). In this same novel, "papist" is translated by "católico ('catholic')" or by "profesar el catolicismo ('to profess catholism')", expressions that make reference to the same concept but which avoid the negative connotations associated with the original term.

In Tom Jones, the intention of "raping" Sophia is reduced to a mere "rapto ('kidnapping')":

Are you frightened by the word rape? (1994 [1749]: 679)

¿Os espanta la palabra sola de rapto? (1796, Vol. III: 198)

In the same text, it is interesting to notice that, although "bastard" is translated as "bastardo", the Spanish word is not so negatively loaded as the English one and, therefore, obscenity can be said to be mitigated, as in the following example:

'Why, then', says the squire, 'to tell you plainly, we have been all this time afraid of a son of a whore of a bastard of somebody's, I don't know who, not $\mathrm{l}$. And now here is a confounded son of a whore of a lord, who may be a bastard too for aught I know or care, for he shall never have a daughter of mine by my consent (1994 [1749]: 758).

Sabed, pues, que un bastardo (no sé cierto de quien) nos ha traido la cabeza al retortero perfectamente ... y que orro bastardo sin duda (porque es un 'Lord') quiere ahora mi hija. iPero al diantre si yo consiento en ello! (1796: 116-117)

In the translation of Gulliver's Travels, when an experiment carried out by one of the teachers is described, the word "excrements" is substituted by the much more general and neutral word "producciones ('productions')", apart from omitting the details of the analysis: 
... to take a strict view of their excrements, and from the colour, the odour, the taste, the consistence, the crudeness or the maturity of digestion, form a judgment of their thoughts and designs. Because men are never so serious, thoughtful, and intent, as when they are at stool, which he found by frequent experiment: (1985 [1726]: 235-236)

... y reconociendo sus producciones en aquellos casos comunes, en que se observa que hallándose el espiritu más recogido y sosegado se piensa con más seriedad (1800: 55).

A change of profession is observed in relation to one of the characters in Pamela. In this novel, Mr. B, invents a romance between the clergyman of Lincolnshire and Pamela: "the girl has a love affair with a young clergyman" (1985 [1740]: 124). In the Spanish text, this romance becomes "una correspondencia con su Secretario ("a correspondence with her secretary")" (1799: Vol. I: 159). Apart from the change in the type of relationship, the important aspect here is the change of profession, because it has many implications for the rest of the novel. One of these implications is the need of introducing in the translation a new character, Mr. Williams' brother, who plays the role of the clergyman in Pamela and Mr. B's wedding, role played originally by the present "secretario ('secretary')".

The second means used in order to mitigate obscenity consists in using a word that belongs to a different (sub)domain and that, although "inappropriate", avoids the negative connotations present in the source text. On these occasions, what we find is translation by an euphemism, that is, "the linguistic equivalent of disinfectant" (Leech, 1974: 53).

This technique is very common in the fragments in which Lady Davers refers to Pamela and to her relation with Mr. B., as in:

...the wench could not talk thus, if she had not been her master's bedfellow (1985 [1740]: 406). ... esta muchacha no hablaria asi si no hubiera tenido con su amo las mayores confianzas (1799, Vol. IV: 16)

'...this girl wouldn't speak in this way if she had not been on terms with her master'

... and lies with him too, does she not? (1985 [1740]: 409)

... se tratarán con toda la familiaridad imaginable (1799, Vol. IV: 21)

'... they treat each other with great familiarity'

Similar examples are provided by the translation of "to be rude" by "intentar familiaridades ("to take too many liberties')", "what he has done" by "lances pasados ("past events')", "attempts upon me" by "insultos ('insults')", "harlot" by "dama ('lady')" or "saluted me most ardently" by "me dio mi amo el parabien ('he congratulated me') del modo mas afectuoso ('affectionately')".

On other occasions, the conversation between Lady Davers and Mrs. Jewkes regarding the type of relationship existing between Pamela and Mr. B., in the Spanish version, is narrated by Pamela in indirect speech, mitigating thus the obscenity and vulgarity present in the source text.

and said, 'Begone, bold woman, as thou art! But yet come hither: dost thou know if that young harlot is to lie with my brother to-night?' [...]' 'I suppose they will not have so much impudence 
as to sleep in one room while I am in the house; but I dare say they have been bed-fellows' (1985 [1740]: 433).

En fin, la pregunta se reducia á saber si estábamos casados, y en qué quarto habia yo de dormir; (1799, Vol. IV: 103)

The same strategy is used in order to hide Sir Simon's greetings, which could be considered quite disrespectful.

Sir Simon said, 'Good neighbour, by your leave'; and, sluting me, added, 'Now will I say, that I have kissed the loveliest maiden in England' (1985 [1740]: 321)

El caballero S... me hizo un cumplimento muy expresivo... (1799, Vol. III: 55)

Likewise, in Robinson Crusoe the fact that "one of our men offer'd some rudeness to the wench that was with her" (1990 [1719]: 379) is translated as "supimos que un marinero nuestro habia infringido el tratado ('has broken the agreement')" (1846: 126), since the rape that is implied in the original would have sounded too offensive.

Although of little relevance to the present analysis, it is interesting to mention a third technique used in order to mitigate the negative evaluation, as is the addition of the translator's comments about the text. In this case, the source text is rendered almost literally, but the translator, conscious of the negative load of the text, decides to incorporate a note or moralist comment. The translator of Tom Jones, for instance, considers that what seems to be an incest committed by the main character could be too offensive for the reader, so he decides to include a comment anticipating the ending.

'Why, then, the Lord have mercy upon your soul and forgive you,' cries Patridge, 'but as sure as I stand here alive, you have been abed with your mother.' (1994 [1749]: 791)

Pues de ese modo, exclamó con dolor Patridge jel cielo tenga piedad de nosotros! Porque ó yo no estoy en mí, ó esa muger es vuestra madre (a).

(a) Se suplica al lector que suspenda eljuicio, á pesar de todas las apariencias que encontrará de ser cierta esta especie; porque ¿quiên sabe lo que puede venir todavía? Por otra parte, somos tan zelosos de su gusto que no queremos privarle del de la sorpresa, adelantándole la solucion de este enigma (1796, Vol. IV: 183).

So far we have mentioned two strategies, omission and mitigation of the negative evaluation, both used with the intention of avoiding or reducing the presence of obscenity in the translation. The third strategy used by translators can be just the opposite, the augmentation of the negative evaluation.

As stated before, the translator's decision is always motivated by the analysis, previous to the translation process, that $\mathrm{s} / \mathrm{he}$ makes of the demands of the target society. In this respect, we will show how the 1978 translation of Fanny Hill can be characterized by the incorporation of many obscene elements, not present in the source text, but, nevertheless, demanded by the reader at that time. The translator of the 1978 version tried to adapt the text to the rhetorical features of a pornographic novel, whereas the 1977 translation, as will 
be illustrated in the following examples, aims at maintaining the affluence of metaphors present in Cleland's novel, consequently distancing itself from the features that characterize a pornographic novel nowadays.

We mentioned before some references to the female organ that were made more explicit, omitting the metaphor present in the source text, such as the translation of "the young tendrils of that moss" (1985 [1749]: 49) by "los rizos ("curls') de aquel musgo" (1978: 29). Another example is the rendering of the euphemism "the small of his back" as "sus nalgas ('buttocks')" (cf. "al acabar la espalda").

The luxuriant swell of flesh that rose from the small of his back, and terminated its double cope at where the things are sent off, perfectly dazzled one with its watery glistening gloss (1985 [1749]: 140).

Además, la exuberante hinchazón de la carne que constituía sus nalgas y terminaba su doble redondez donde comienzan los muslos cegaba literalmente con su brillo mojado (1978: 123). Más abajo, al acabar la espalda, la carne se hendía bellamente y terminaba en dos alturas de las que brotan los muslos, que brillabany deslumbraban charoladas por el agua (1977: 119).

The same tendency can be observed in relation to verbs designating romance acts. The meaning implied by the euphemism "discharge" ("descargar" in the 1977 version) is made explicit in "eyaculación ("ejaculation')". Verbs that belong to the domain of emotions are translated by verbs of sensations, thus, "stirred beyond bearing" ("exaltada insoportablemente" in the 1977 version) becomes "excitada ("aroused') a más no poder"; "thrilled to the very soul of me" ("me conmovieron hasta el alma" in 1977) becomes "me excitaba ('aroused') hasta el alma". Verbs that designate "innocent' physical relations are translated by verbs designating more sexual, physical relations, thus "hugged, clasped" is translated by "sobé y estreché ("pawed and squeezed')" (cf. "abracé y acaricié" in 1977).

This augmentation of the negative load of the word used in the translation can also be seen in relation to the participants in sexual games. "Giddy creatures" is translated as "criaturas casquivanas ('frivolous flighty')" (cf. "alocadas criaturas" in 1977); "dame" becomes "tia ("slut')" (cf. "dama"); "coarse country strammel" is rendered as "ruda jaca ("mare') labriega" (cf. "aquella tosca moza campesina"); " a select reveling band" becomes "una pandilla de parrandistas ('reveller') selectos" (cf. "selecta compañía aficionada a las diversiones"); "beldams" is translated by "brujas ("witch')" (cf. "mujeres").

These examples have shown that in the case of the 1978 translation of Fanny Hill, the tendency is to substitute euphemisms or neutral words by words with clear sexual connotations, thus increasing their negative axiological load.

\section{Conclusions}

In this paper we have presented the new conception of the organization of the lexicon of a language as proposed by the FLM. We have described briefly the four axes around which 
the relevant information associated with each word is coded: syntagmatic, paradigmatic, cognitive and pragmatic axes. Nevertheless, a claim is made to integrate pragmatic information as part of the definition of a word and, therefore, to include it within the paradigmatic axis, instead of treating it as belonging to a separate axis of description.

From this perspective, an analysis of the translation of obscene elements in some literary texts has been offered; such an analysis reveals the important role that lexical choices play in translation and the advantages of the FLM for its study: The organization of the lexicon proposed here not only allows the translator to find an equivalent in the target language, but also to satisfy the demands of the target reader, in this case causing lexical manipulation in translation.

We have referred to the translator's decisions as if they were completely conscious. In fact, the translator takes his decisions in an apparently intuitive and automatic way, but it must be noticed that intuition is trained. Therefore, most of the time, the more unconscious a decision seems to be, the more faithfully it fits the demands of habit, that is always the exact correlate of the prevailing order of things.

\section{Notes}

1. In the FLM a basic distinction is established between primary and derived lexical units. This distinction is described by Faber and Mairal Usón in the following terms: "Lexical units forming the core vocabulary of the lexicon are those which cannot be derived by word-formation rules [...]. In contrast, the derived lexicon constitutes a separate component and runs parallel to the grammatical one" (1998: 5).

2. Terms adopted form Cortés Rodríguez (1986).

3. Predicates are understood as the lexical elements that express a property or a relation among entities (Dik, 1997).

4. These are the basic types of predicates distinguished by Dik (1997). Other linguists, working within the FG framework, add prepositionals (Mackenzie \& Hannay, 1982) and adverbials (Hengeveld, 1992) to this list.

5. Fernández Sánchez (1998) offers an analysis of cognitive abilities of verbs of possession from a Functional-Lexematic perspective. In this line, Faber and Pérez (1993) present an interesting explanation of the metaphorical projections from the lexical field of light.

6. For a detailed analysis of this metaphor in Old English, see Mele Marrero and Cortés Rodríguez (2000).

7. It was not translated until the beginning of the $20^{\text {th }}$ century, when it appeared as Fanny Hill (1977) and Memorias de una cortesana (1978).

8. Our attention will focus on fragments that can be labeled as transgressive within the sociocultural and political background where they were translated (that is, $18^{\text {th }}$ century Spain).

9. In the case of Fanny Hill, two translations were published at the beginning of the century, but they are no longer available at the Biblioteca Nacional.

10. When considered necessary, a backtranslation is offered between single quotation marks in order to make clear to a non-Spanish reader in what sense the Spanish translation deviates from the source text. 
11. Although, as can be seen in some of the previous examples, sometimes the authors of the source texts try to avoid obscenity using dashes, the meaning is unmistakenly recognized.

12. In all the examples, the emphasis, in bold face, has been added.

\section{Works Cited}

Baker, Mona (1992): In Other Words. London: Routledge.

Butler, Christopher, Mairal, Ricardo, Martín Arista, Javier and Francisco J. Ruiz de Mendoza (eds.) (1999): Nuevas perspectivas en Gramática Funcional. Barcelona: Ariel.

Calañas Continente, José Antonio (1998): "A Functional-Lexematic Description of the Verbal Core Lexicon of the German Language". In H. Olbertz, K. Hengeveld and Jesús Sánchez García, eds., The Structure of the Lexicon in Functional Grammar. Amsterdam: John Benjamins, 25-46.

Cortés Rodríguez, Francisco (1986): Análisis Lexemático-Funcional de los adjetivos de percepciones gustativas y olfativas en inglés y español. Unpublished MA dissertation, Universidad de Granada.

Cortés Rodríguez, Francisco J., González Orta, Marta, Hernández Pérez, Beatriz, Martín Díaz, $\mathbf{M}^{\mathrm{a}}$ Auxiliadora, Mele Marrero, Margarita and $\mathbf{M}^{\mathrm{a}}$ Jesús Pérez Quintero (eds.) (2000). Variation and Variety in Medieval English Language and Literature. Madrid: Kadle Books.

Dik, Simon C. (1978): Stepwise Lexical Decomposition. Lisse: The Peter de Reader Press.

(1997): The Theory of Functional Grammar. Part I \& II. Berlin: Mouton de Gruyter.

Faber, Pamela and Chantal Pérez (1993): "Image Schemata and Light: A Study in Contrastive Domains in English and Spanish". Atlantis, XV (1/2): 117-134.

Faber, Pamela and Ricardo Mairal Usón (1997): "Towards a Typology of Predicate Schemata in a Functional-lexematic Model". In G. Wotjak, ed., Towards a Functional Lexicology. Frankfurt am Main: Peter Lang, 11-36.

. (1998): "Methodological Criteria for the Elaboration of a Functional Lexicon-Based Grammar of the Semantic Domain of Cognitive Verbs". In H. Olbertz, K. Hengeveld and Jesús Sánchez Garcia, eds., The Structure of the Lexicon in Functional Grammar. Amsterdam: John Benjamins, 3-24.

. (1999). Constructing a Lexicon of English Verbs. Berlin: Mouton de Gruyter.

Fernández Sánchez, Eulalio (1998): "Cognitive Abilities from a Functional-Lexematic Perspective". In H. Olbertz, K. Hengeveld and Jesús Sánchez García, eds., The Structure of the Lexicon in Functional Grammar. Amsterdam: John Benjamins, 65-84.

Fortescue, Michael, Harder, Peter and Lars Kristoffersen (eds.) (1992): Layered Structure and Reference in a Functional Perspective. Amsterdam: John Benjamins.

Halliday, M.A.K. (1985): An Introduction to Functional Grammar. London: Edward Arnold. Hartmann, Reinhart (ed.) (1984): LEX'eter' 83: Proceedings of the International Conference on Lexicography. Tübingen: Niemeyer.

Hengeveld, Kees (1992): "Parts of Speech". In M. Fortescue, P. Harder and K. Lars Kristoffersen, eds., Layered Structure and Reference in a Functional Perspective. Amsterdam: John Benjamins, 29-53.

Hoinkes, Ulrich (ed.) (1995): Panorama der Lexikalischen Semantik [Panorama of Lexical Semantics]. Tübingen: Gunter Narr. 
Jiménez Hurtado, Catalina (1997): "Hacia una Lexicología Funcional Contrastiva AlemánEspañol. La codificación de la cultura en los campos léxicos y sus aplicaciones para la traducción". In G. Wotjak, ed., Towards a Functional Lexicology. Frankfurt am Main: Peter Lang, 185-208.

. (1998): "Prototipos pragmáticos en el lexicón. (La inclusión de la pragmática en el concepto de campo léxico)". In G. Wotjak, ed., Towards a Functional Lexicology. Frankfurt am Main: Peter Lang, 275-301.

Krzeszowski, Tomasz P. (1990): "The Axiological Aspect of Idealized Cognitive Models". In J.

Tomaszczyk and B. Lewandowska-Tomaszczyk, eds., Meaning and Lexicography.

Amsterdam: John Benjamins, 135-165.

Leech, Geoffrey (1974): Semantics. Harmondsworth: Penguin Books.

Lyons, John (1977): Semantics. Vol. 1 \& 2. Cambridge: C.U.P.

Mackenzie, J. Lachlan and Mike Hannay (1982): "Prepositional Predicates and Focus Constructions in a Functional Grammar of English". Lingua, 56: 43-57.

Mairal Usón, Ricardo (1999): "El componente lexicón en la Gramática Funcional". In C. Butler, R. Mairal, J. Martín Arista and F. J. Ruiz de Mendoza, eds., Nuevas perspectivas en Gramática Funcional. Barcelona: Ariel, 41-98.

Martín Mingorance, Leocadio (1984): "Lexical Fields and Stepwise Lexical Decomposition in a Contrastive English-Spanish Verb Valency Dictionary". In R. Hartmann, ed., LEX'eter' 83: Proceedings of the International Conference on Lexicography. Tübingen: Niemeyer, 226-236. . (1987): "Classematics in a Functional-Lexematic Grammar of English". In C. Olivares, ed., Actas del X Congreso de la Asociación Española de Estudios Anglo-Norteamericanos [Proceedings of the X Conference of the Spanish Association of Anglo-American Studies]. Zaragoza: University of Zaragoza, 377-382.

. (1990): "Functional Grammar and Lexematics in Lexicography". In J. Tomaszczyk and B. Lewandowska-Tomaszczyk, eds., Meaning and Lexicography. Amsterdam: John Benjamins, 227-253.

. (1995): "Lexical Logic and Structural Semantics: Methodological Underpinnings in the Structuring of a Lexical Database for Natural Language Processing". In U. Hoinkes, ed., Panorama der Lexikalischen Semantik [Panorama of Lexical Semantics]. Tübingen: Gunter Narr, 461-474.

. (1998): "Pragmatic Features in the Lexicon of a Functional Grammar". In A. Martín Rubiales, ed., El Modelo Lexemático-Funcional. Universidad de Granada, 91-99.

Martín Rubiales, Amalia, (ed.)(1998): El ModeloLexemático-Funcional. Universidad de Granada. Mele Marrero, Margarita and Francisco J. Cortés Rodríguez (2000): "The Medieval Expression of the Container Model in Sexual Differentiation". In F. Cortés Rodríguez, M. González Orta, B. Hernández Pérez, $M^{a}$ A. Martín Díaz, M. Mele Marrero and $\mathbf{M}^{\mathrm{a}}$ J. Pérez Quintero, eds., Variation and Variety in Medieval English Language and Literature. Madrid: Kadle Books. Olbertz, Hella, Hengeveld, Kees and Jesús Sánchez García (eds.) (1998): The Structure of the Lexicon in Functional Grammar. Amsterdam: John Benjamins.

Olivares, Carmen (ed.) (1987): Actas del X Congreso de la Asociación Española de Estudios Anglo-Norteamericanos [Proceedings of the $\mathrm{X}$ Conference of the Spanish Association of Anglo-American Studies]. Zaragoza: University of Zaragoza. 
Snell-Hornby, Mary (1990): "Dynamics in Meaning as a Problem for Bilingual Lexicography". In J. Tomaszczyk and B. Lewandowska-Tomaszczyk, eds., Meaning and Lexicography. Amsterdam: John Benjamins, 209-226.

Tomaszczyk, Jerzy and Barbara Lewandowska-Tomaszczyk (eds.) (1990): Meaning and Lexicography. Amsterdam: John Benjamins.

Wotjak, Gerd (ed.) (1997): Towards a Functional Lexicology [Hacia una lexicología funcional]. Frankfurt am Main: Peter Lang. . (1998): Teoria del campo y semántica léxica [Théorie des champs et sémantique lexicale]. Frankfurt am Main: Peter Lang.

\section{Source Texts and Translations}

Alegret de Mesa, José (1849-50): Aventuras de Robinson Crusoe. Madrid: D. Nicolás Cabello. Anonymous (1799): Pamela Andrews ó la virtud premiada. Madrid: Imprenta Real. . (1846): Aventuras de Robinson Crusoe. Méjico: D. Ignacio Cumplido. . (1978): Memorias de una cortesana. Barcelona: Producciones Editoriales.

Cleland, John (1985): Fanny Hill or Memoirs of a Woman of Pleasure. London: Penguin, 1749. Defoe, Daniel (1990): Robinson Crusoe. London \& Glasgow: Collins, 1719.

De Ordejon, Ignacio (1796): Tom Jones ó el Expósito. Madrid: Imprenta de D. Benito Cano. Fielding, Henry (1994): The History of Tom Jones. London: Penguin, 1749.

Lane, Frank (1977): Fanny Hill. Madrid: Akal.

Máximo Spartal, Ramón (1800): Viages del capitan Lemuel Gulliver á diversos paises remotos. Imprenta Plasencia.

Richardson, Samuel (1985): Pamela. London: Penguin, 1740.

Swift, Jonathan (1985): Gulliver's Travels. London: Penguin, 1726.

\section{Dictionaries}

Carbonell Basset, Delfín(1992):Diccionariomalsonante inglés-español/español-inglés. Madrid: Istmo. . (1979): Collins Spanish-English /English-Spanish Dictionary. Barcelona: Grijalbo. (1985): Collins English Dictionary. London \& Glasgow: Collins. (1987): Collins Cobuild English Language Dictionary. London \& Glasgow: Collins. (1993): Longman Language Activator. London: Longman.

MacArthur, Tom (1981): Longman Lexicon of Contemporary English. London: Longman. Moliner, María (1981): Diccionario de uso del español. Madrid: Gredos. 